\title{
Morphological, Physiological, and Structural Responses of Two Species of Artemisia to NaCl Stress
}

\author{
Zhi-Yong Guan, ${ }^{1,2}$ Yi-Ji Su, ${ }^{1}$ Nian-Jun Teng, ${ }^{1}$ Su-Mei Chen, ${ }^{1}$ Hai-Nan Sun, ${ }^{1}$ \\ Chu-Ling Li, ${ }^{1}$ and Fa-Di Chen ${ }^{1,2}$ \\ ${ }^{1}$ College of Horticulture, Nanjing Agricultural University, Nanjing 210095, China \\ 2 Jiangsu Province Engineering Lab for Modern Facility Agriculture Technology \& Equipment, Nanjing 210095, China \\ Correspondence should be addressed to Fa-Di Chen; chenfd@njau.edu.cn
}

Received 19 July 2013; Accepted 5 September 2013

Academic Editors: R. M. Mian, T. Takamizo, and S. D. Yeh

Copyright (C) 2013 Zhi-Yong Guan et al. This is an open access article distributed under the Creative Commons Attribution License, which permits unrestricted use, distribution, and reproduction in any medium, provided the original work is properly cited.

Effects of salt stress on Artemisia scoparia and A. vulgaris "Variegate" were examined. A. scoparia leaves became withered under $\mathrm{NaCl}$ treatment, whereas A. vulgaris "Variegate" leaves were not remarkably affected. Chlorophyll content decreased in both species, with a higher reduction in $A$. scoparia. Contents of proline, MDA, soluble carbohydrate, and $\mathrm{Na}^{+}$increased in both species under salt stress, but A. vulgaris "Variegate" had higher level of proline and soluble carbohydrate and lower level of MDA and Na ${ }^{+}$. The ratios of $\mathrm{K}^{+} / \mathrm{Na}^{+}, \mathrm{Ca}^{2+} / \mathrm{Na}^{+}$, and $\mathrm{Mg}^{2+} / \mathrm{Na}^{+}$in A. vulgaris "Variegate" under $\mathrm{NaCl}$ stress were higher. Moreover, A. vulgaris "Variegate" had higher transport selectivity of $\mathrm{K}^{+} / \mathrm{Na}^{+}$from root to stem, stem to middle mature leaves, and upper newly developed leaves than $A$. scoparia under $\mathrm{NaCl}$ stress. A. vulgaris "Variegate" chloroplast maintained its morphological integrity under $\mathrm{NaCl}$ stress, whereas A. scoparia chloroplast lost integrity. The results indicated that A. scoparia is more sensitive to salt stress than A. vulgaris "Variegate." Salt tolerance is mainly related to the ability of regulating osmotic pressure through the accumulation of soluble carbohydrates and proline, and the gradient distribution of $\mathrm{K}^{+}$between roots and leaves was also contributed to osmotic pressure adjustment and improvement of plant salt tolerance.

\section{Introduction}

Salinity is one of the major environmental stresses affecting crop productivity. Excessive irrigation and poor drainage facilities are the main factors causing soil salinity in agricultural lands, and about one-third of world irrigated land is being affected by soil salinity $[1,2]$. Injury resulting from salinity is mainly symbolized as ion toxicity, osmotic stress, and nutritional imbalance [3]. $\mathrm{NaCl}$ stress leads to higher concentration of $\mathrm{Na}^{+}$in plant organs, and the excessive accumulation of $\mathrm{Na}^{+}$can inhibit plant growth and development [4]. To maintain normal physiological metabolism, the plant restricts $\mathrm{Na}^{+}$entrance through selective absorption by roots, which promotes the efflux and compartmentation of $\mathrm{Na}^{+}$, and maintains high ratio of $\mathrm{K}^{+} / \mathrm{Na}^{+}$balance [5]. Thus, the mechanism of salt tolerance for most of crops is to keep a low concentration of $\mathrm{Na}^{+}$and high absorption of $\mathrm{K}^{+}$[6]. Previous research on ion distribution in plants under salt stress has been conducted on soybeans (Glycine max), wheat (Triticum aestivum), cotton (Gossypium hirsutum), sorghum (Sorghum bicolor), Solanum sp., and Cucumis sativus [7-9], while little information is available on Chrysanthemum and its related genera.

Artemisia, belonging to Compositae, is closely related to Chrysanthemum. The species in Artemisia have plenty of valuable characters that Chrysanthemum cultivars do not have, such as cold tolerance and aphid resistance [10, 11]. Therefore, many Artemisia species are very important germplasm resource during Chrysanthemum breeding with the aim of improving its biotic and abiotic resistance. The collection, evaluation, and selection of wild species of Artemisia are of great significance for future breeding of Chrysanthemum. However, few studies have been conducted to assess salt tolerance in this genus. Therefore, it is very necessary to evaluate their salt tolerance and investigate the mechanism involved in salt tolerance. 
Artemisia scoparia and A. vulgaris "Variegate" are two main species in Artemisia and widely distributed in China $[10,11]$. We therefore used the two species as experimental materials in this study to investigate their morphological, physiological, and structural responses to $\mathrm{NaCl}$ stress. The aim of this study is to evaluate their salt tolerance and related mechanism of salt tolerance and obtain salt-tolerant species for salt-tolerant breeding of Chrysanthemum in the future.

\section{Materials and Methods}

2.1. Plant Material. Artemisia scoparia and A. vulgaris "Variegate" were obtained from the Chrysanthemum Germplasm Resource Preserving Centre, Nanjing Agricultural University, China $\left(32^{\circ} 05^{\prime} \mathrm{N}, 118^{\circ} 90^{\prime} \mathrm{E}\right)$.

2.2. NaCl Treatment. Shoot cuttings of A. scoparia and A. vulgaris "Variegate" were rooted and grown in a sand bed from the beginning of April 2012. Rooted seedlings at 6-7 leaf stage were selected and then transplanted into $300 \mathrm{~mL}$ plastic pots filled with quartz sand that has been washed by acid and water successively. Hoagland nutrient solution was provided to plants in a circulation case (volume = $23.4 \mathrm{~L}$ ), with aeration for $24 \mathrm{~h} / \mathrm{d}$. After 1 week, salt treatment was performed by supplementing the nutrient solution with $200 \mathrm{mmol} \cdot \mathrm{L}^{-1} \mathrm{NaCl}$. A set of plants growing on Hoagland solution alone was kept as a control (CK). Plants were treated under hydroponic cultivation for 14 days; the stress treatment solutions were renewed every 3 days. Each treatment had 15 plants. All the plants were maintained in a greenhouse at $160 \mathrm{~mol} \cdot \mathrm{m}^{-2} \cdot \mathrm{s}^{-1} \mathrm{PAR}, 12 \mathrm{~h}$ photoperiod, average temperature of $25^{\circ} \mathrm{C}$ and relative humidity of $70 \%$.

2.3. Determination of Physiological Parameters. Chlorophyll contents were determined by ethanol extraction colorimetry. $0.2 \mathrm{~g}$ fresh leaves were put into mortar and grinded with the mixture of leaves, quartz sand, calcium carbonate powder, and $2-3 \mathrm{~mL} 95 \%$ ethanol. After the volume was determined, the absorbance values were measured under $665 \mathrm{~nm}$, and $649 \mathrm{~nm}$. The contents were calculated according to the following formula:

$$
\begin{aligned}
& C_{a}=13.95 A_{665}-6.88 A_{649}, \\
& C_{b}=24.96 A_{649}-7.32 A_{665} .
\end{aligned}
$$

Malondialdehyde (MDA) contents were determined by Tribromoarsenazo (TBA) colorimetry. $5 \mathrm{~mL} \mathrm{5 \%} \mathrm{TCA} \mathrm{was}$ added to $0.5 \mathrm{~g}$ fresh leaves. The mixture was centrifuged under $3000 \mathrm{r} / \mathrm{min}$ for $10 \mathrm{~min}$ after grinded. $2 \mathrm{~mL} 0.67 \%$ TBA was added into $2 \mathrm{~mL}$ supernatant. The mixed solution was put in $100^{\circ} \mathrm{C}$ boiling bath for $30 \mathrm{~min}$. After being cooled and centrifuged, the absorbance values were measured under $450 \mathrm{~nm}, 532 \mathrm{~nm}$ and $600 \mathrm{~nm}, C(\mu \mathrm{mol} / \mathrm{L})=6.45\left(A_{532}-\right.$ $\left.A_{600}\right)-0.56 A_{450}$.

With regard to proline content, $0.5 \mathrm{~g}$ of fresh leaves was put into big tubes and $5 \mathrm{~mL}$ of $3 \%$ sulfosalicylic acid aqueous solution was added. The mixture was extracted in the boiling water for $10 \mathrm{~min}$ and $2 \mathrm{~mL}$ of them was taken into clear tubes with glass plugs. $2 \mathrm{~mL}$ acetic acid and $2 \mathrm{~mL}$ acidicninhydrin were added and put in the boiling bath for $30 \mathrm{~min}$. After being cooled and shaken for $30 \mathrm{~s}, 4 \mathrm{~mL}$ toluene was added with a short period of standing. The upper liquor was centrifuged under $3000 \mathrm{r} / \mathrm{min}$ for $5 \mathrm{~min}$ in $10 \mathrm{~mL}$ tubes, and the absorbance values were measured under $520 \mathrm{~nm}$. Proline contents were calculated according to the standard curve: proline content $(\%)=\left(X \times V_{T}\right) /\left(W \times V_{S} \times 10^{6}\right) \times 100$.

For the content of soluble carbohydrate, the phenol method was carried out. $0.10-0.30 \mathrm{~g}$ of fresh leaves was taken into tubes and $5-10 \mathrm{~mL}$ diluted water was added. Tubes sealed with plastic films were extracted in boiling water twice, 30 min each time. After filtration and volume determined, the absorbance values were measured under $485 \mathrm{~nm}$, and contents were calculated according to the standard curve: soluble carbohydrate content $(\%)=\left(C \times V_{T} \times N\right) /\left(W \times V_{S} \times\right.$ $\left.10^{6}\right) \times 100$.

In ion measurement, the seedlings were washed and divided into four parts: roots, stems, middle leaves (the third and fourth mature leaves counting from the apex) and upper leaves (the newly unrolled leaves after treatment). Then enzymes were deactivated under $105^{\circ} \mathrm{C}$ for $25 \mathrm{~min}$ and the dry weight of samples was measured after they were dried to constant weight under $70^{\circ} \mathrm{C}$. After being grinded, the samples were put into the dryer for storage. $50 \mathrm{mg}$ of dry samples; taken into tubes, then $20 \mathrm{~mL}$ of water was added and vortexed. The samples were filtered into $25 \mathrm{~mL}$ volumetric flask after staying in boiling water bath for $1.5 \mathrm{~h}$. The contents of $\mathrm{K}^{+}, \mathrm{Na}^{+}, \mathrm{Ca}^{2+}$, and $\mathrm{Mg}^{2+}$ in the nutrient solutions of each treatment were measured by Optimal 2100 DV Inductive Coupling Plasma Emission Spectrograph (Perkin Elmer Co.).

The selective ratios of $\mathrm{K}^{+}$and $\mathrm{Na}^{+}$absorption and transport $\left(S_{\mathrm{K}, \mathrm{Na}}\right)$ were calculated as follows:

(i) ion absorption $S_{\mathrm{K}, \mathrm{Na}}=\operatorname{root}\left(\left[\mathrm{K}^{+}\right] /\left[\mathrm{Na}^{+}\right]\right) /$medium $\left(\left[\mathrm{K}^{+}\right] /\left[\mathrm{Na}^{+}\right]\right)$;

(ii) ion transport $S_{\mathrm{K}, \mathrm{Na}}=\operatorname{sink}$ organ $\left(\left[\mathrm{K}^{+}\right] /\left[\mathrm{Na}^{+}\right]\right) /$source organ $\left(\left[\mathrm{K}^{+}\right] /\left[\mathrm{Na}^{+}\right]\right)$.

2.4. Transmission Electron Microscopy. Tissue samples for ultrastructural observation were taken from the middle section of the second and third leaf counting from the apex. Leaf segments with approximately $0.5 \mathrm{~mm}$ in length were fixed with $2.5 \%$ glutaraldehyde in phosphate buffer $(\mathrm{pH} 7.2)$ for $3 \mathrm{~h}$ at room temperature and then postfixed with $1 \% \mathrm{OsO}_{4}$ in the same buffer with the addition of sucrose $(25 \mathrm{mg} / \mathrm{mL})$ for $2 \mathrm{~h}$. Subsequently, the samples were dehydrated in a series of gradient ethanol $(30,40,50,60,70$, and 96\%), acetone, and propylene oxide. The samples were embedded in Epon 812 and polymerized for 3 days at temperature rising from 37 to $60^{\circ} \mathrm{C}$. The sections were produced using an LKB-111 microtome (Sweden) and stained with a saturated solution of aqueous uranyl acetate for $10 \mathrm{~min}$ at $60^{\circ} \mathrm{C}$ and then for $10 \mathrm{~min}$ with aqueous lead citrate. Preparations were examined under a transmission electron microscope (JEOL Ltd, Tokyo, Japan) $[12,13]$. 


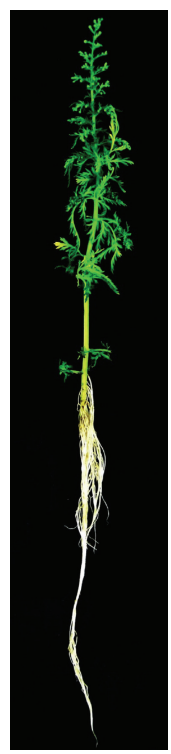

(a)

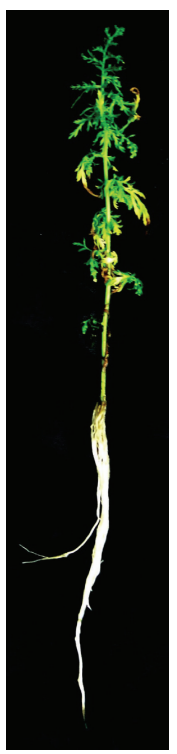

(b)

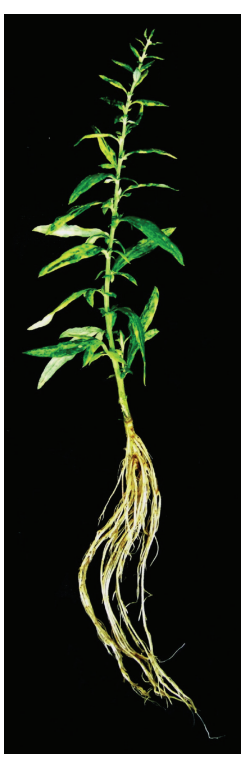

(c)

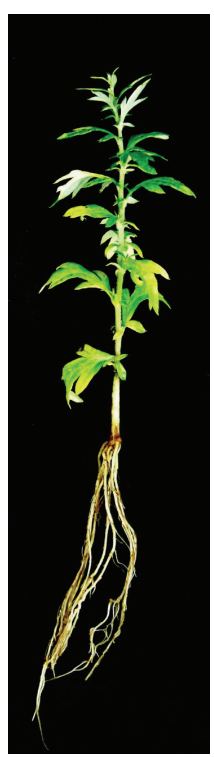

(d)

Figure 1: Morphological response of A. scoparia and A. vulgaris "Variegate" to salt stress. (a), (c) The plants of A. scoparia and A. vulgaris "Variegate" grown under controls, respectively. (b), (d) The plants treated with $\mathrm{NaCl}$, respectively.

2.5. Statistical Analysis. The data were subjected to a one-way analysis of variance and statistical significance $(P<0.05)$ of differences among means was judged by Duncan's New Multiple Range Test using the SPSS software 16.0 (SPSS Inc., Chicago, IL, USA).

\section{Results}

3.1. Morphological Characteristics. Compared with A. vulgaris "Variegate," A. scoparia was more sensitive to $\mathrm{NaCl}$ treatment. For example, most of $A$. scoparia leaves withered and became brown after $\mathrm{NaCl}$ stress, whereas $A$. vulgaris "Variegate" was seldom affected by $\mathrm{NaCl}$ and only a few leaves turned yellow (Figure 1).

3.2. Chlorophyll Content. $\mathrm{NaCl}$ stress significantly reduced the chlorophyll content of $A$. scoparia to $78 \%$ of the untreated control plants, but the chlorophyll content of $A$. vulgaris "Variegate" only had a slight reduction of $5 \%$ relative to the control. The results indicate that A. vulgaris "Variegate" was less affected by $\mathrm{NaCl}$ stress compared with $A$. scoparia (Figure 2(A)).

3.3. MDA Content. $\mathrm{NaCl}$ treatment significantly increased MDA content in the leaves of $A$. scoparia, but MDA content in the leaves of $A$. vulgaris "Variegate" slightly increased under $\mathrm{NaCl}$ stress. For instance, MDA content in the leaves of $A$. scoparia increased by around $34 \%$ after $\mathrm{NaCl}$ treatment, while the level of increase in A. vulgaris "Variegate" was only about $3 \%$. As MDA content in the leaves is usually proportional to the damage level of plant membrane, A. vulgaris "Variegate" was more tolerant to salt stress than A. scoparia (Figure 2(B)).
3.4. Proline Content. Proline content increased slightly in the leaves of $A$. scoparia but significantly in the leaves of $A$. vulgaris "Variegate". Compared with the controls, $\mathrm{NaCl}$ treatment resulted in a slight increase of about $11 \%$ in A. scoparia and a significant increase of around 63\% in A. vulgaris "Variegate", respectively (Figure $2(\mathrm{C})$ ). Because proline is one of the most important substances involved in osmoregulation and reducing membrane injury when plants are subject to abiotic stresses including salt stress, it can help increase plant tolerance to abiotic stresses. Therefore, the results presented here indicate that A. vulgaris "Variegate" may have a higher tolerance to salt stress than A. scoparia.

3.5. Soluble Carbohydrate Content. Soluble carbohydrate content significantly increased in leaves of both $A$. scoparia and A. vulgaris "Variegate" under salt stress, but there is a higher increase level in the latter than in the former species. For example, $\mathrm{NaCl}$ treatment led to an increase of about $64 \%$ in soluble carbohydrate content in leaves of $A$. scoparia but around $228 \%$ in the leaves of $A$. vulgaris "Variegate", relative to the controls (Figure 2(D)).

3.6. Allocation of $\mathrm{Na}^{+}, \mathrm{K}^{+}, \mathrm{Ca}^{2+}$, and $\mathrm{Mg}^{2+}$. $\mathrm{NaCl}$ stress significantly increased $\mathrm{Na}^{+}$content in different parts of both species. However, there is a higher level of increase in $\mathrm{Na}^{+}$ content in roots, stems, and upper leaves of $A$. scoparia than in $A$. vulgaris "Variegate". For instance, $\mathrm{Na}^{+}$content in roots, stems, and upper leaves of $A$. scoparia was $8.34,5.24$, and 9.46 times of that in the corresponding parts of this species under the control, respectively, whereas the data were 4.67, 2.09 and 3.90 (Table 1). In addition, after $\mathrm{NaCl}$ treatment, $\mathrm{Na}^{+}$content in all the parts of $A$. scoparia, especially leaves, was much higher than those of A. vulgaris "Variegate". 


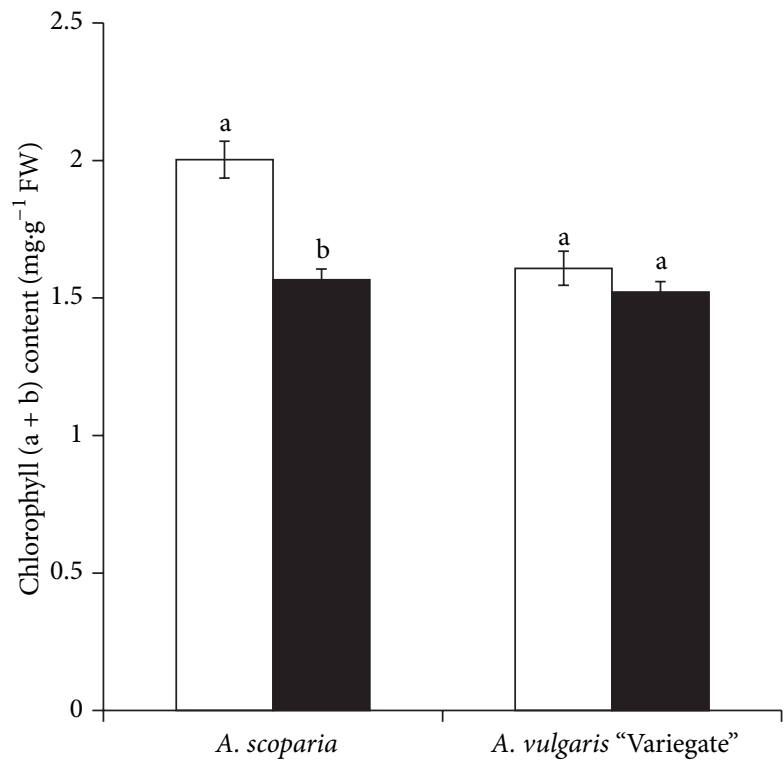

(A)

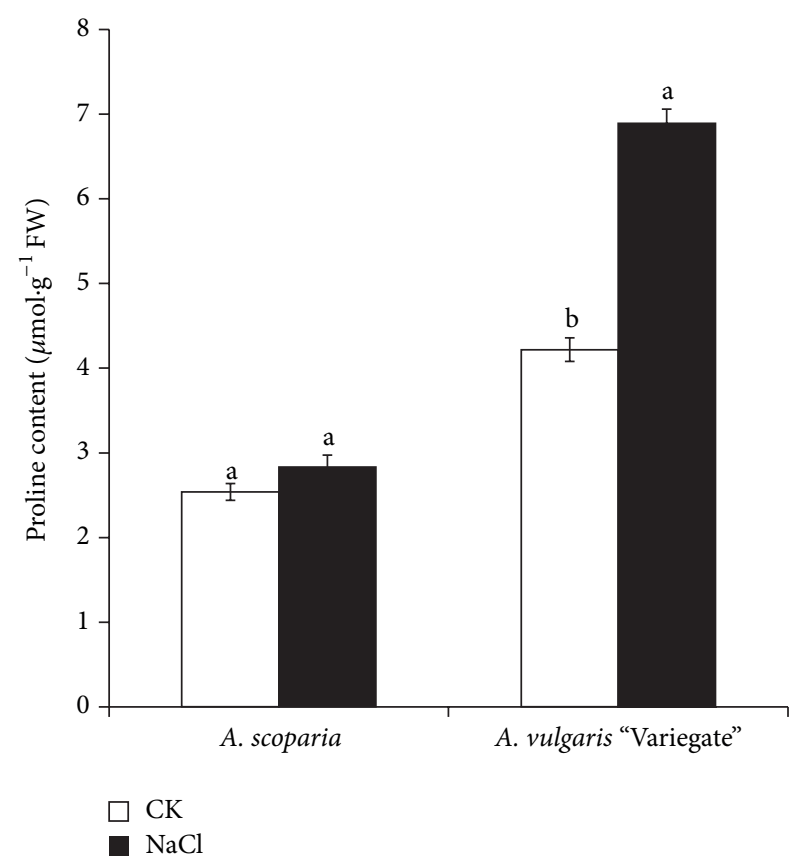

(C)

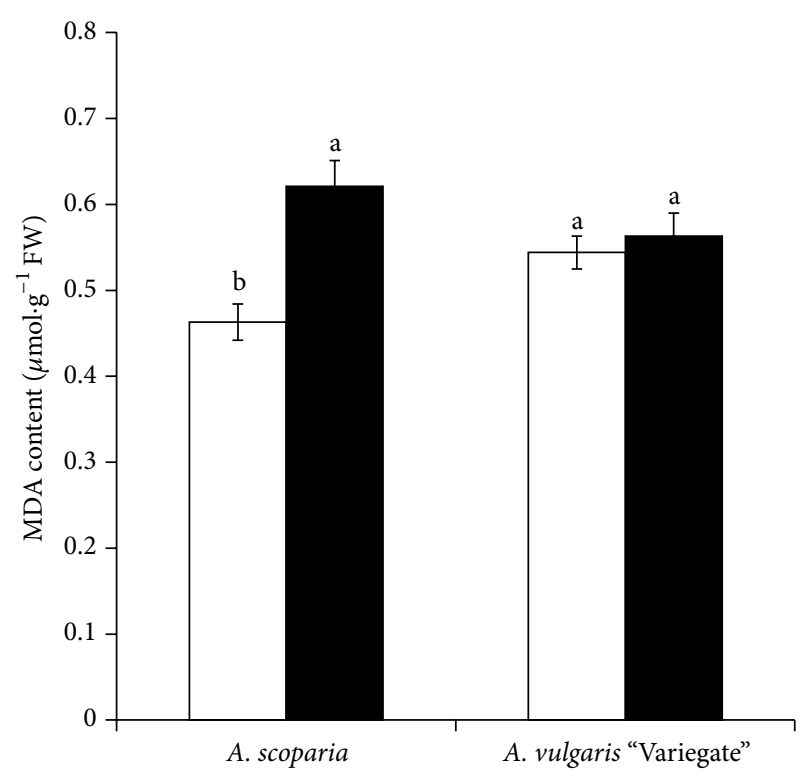

(B)

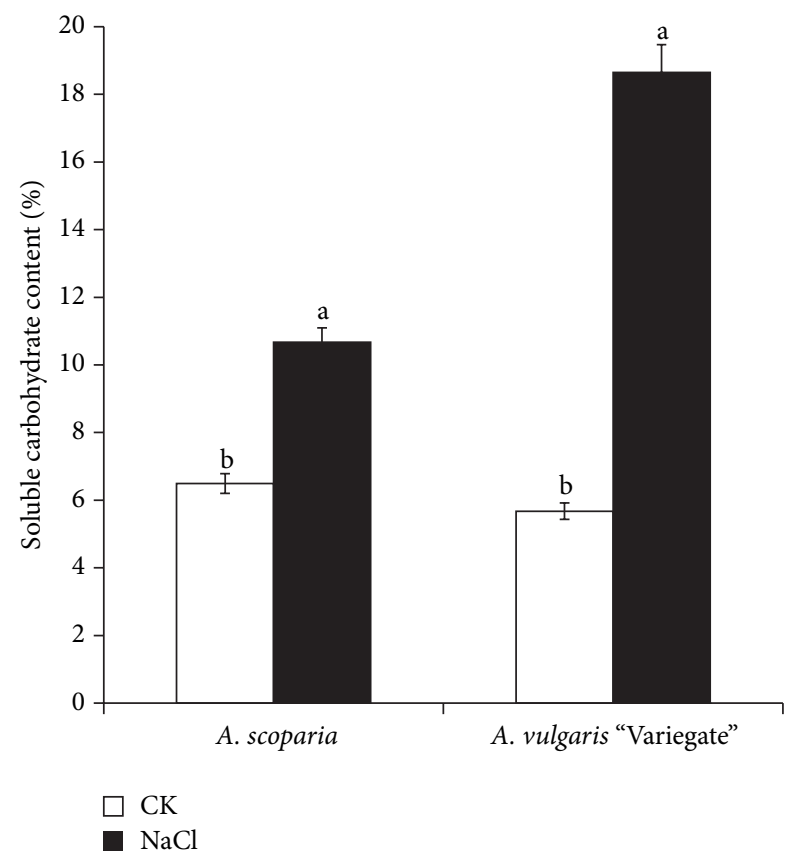

(D)

FIGURE 2: Effect of $\mathrm{NaCl}$ on contents of chlorophyll $(\mathrm{a}+\mathrm{b}), \mathrm{MDA}$, proline, and soluble carbohydrate content in leaves. $\mathrm{CK}: 0 \mathrm{mmol} \cdot \mathrm{L}^{-1} \mathrm{NaCl}$ treatment; $\mathrm{NaCl}: 200 \mathrm{mmol} \cdot \mathrm{L}^{-1} \mathrm{NaCl}$ treatment. The different letters represent significant difference at $P<0.05$ between $\mathrm{CK}$ and $\mathrm{NaCl}$ by Duncan's New Multiple Range Test. Error bars represent standard errors.

$\mathrm{NaCl}$ stress signicantly decreased $\mathrm{K}^{+}$content in roots and stems of both species but did not significantly affect $\mathrm{K}^{+}$ content in leaves of the two species. In addition, there were higher reductions in $\mathrm{K}^{+}$content in roots and stems of $A$. scoparia than in those of A. vulgaris "Variegate" after both species were exposed to $\mathrm{NaCl}$ stress. For example, the ratios $(\mathrm{NaCl}: \mathrm{CK})$ of $\mathrm{K}^{+}$content in roots and stems of $A$. scoparia were 0.46 and 0.74 , respectively, and the corresponding data for those of $A$. vulgaris "Variegate" were 0.60 and 0.82 , respectively. However, the ratios $(\mathrm{NaCl}: \mathrm{CK})$ for middle and upper leaves were 0.94 and 0.97 in A. scoparia and 1.09 and 1.00 in A. vulgaris "Variegate" (Table 2).

In contrast to other cations, levels of $\mathrm{Ca}^{2+}$ in the plant organs of both species grown in absence of $\mathrm{NaCl}$ were similar, except that the roots of $A$. vulgaris "Variegate" had levels about three times higher than those of $A$. scoparia. When 
TABLE 1: Effects of $\mathrm{NaCl}$ stress on $\mathrm{Na}^{+}$content in different organs of A. scoparia and A. vulgaris "Variegate."

\begin{tabular}{lccccc}
\hline Cultivars & \multirow{2}{*}{ Treatment } & \multicolumn{2}{c}{$\mathrm{Na}^{+}$content $\left(\mathrm{mg}^{-1}\right.$ dry weight $)$} \\
& & Roots & Stems & Middle leaves & Upper leaves \\
\hline \multirow{3}{*}{ A. scoparia } & $\mathrm{CK}$ & $8.10 \pm 0.30 \mathrm{~b}$ & $17.97 \pm 0.54 \mathrm{c}$ & $13.39 \pm 0.59 \mathrm{c}$ & $8.28 \pm 0.27 \mathrm{c}$ \\
& $\mathrm{NaCl}$ & $67.52 \pm 2.18 \mathrm{a}$ & $73.39 \pm 2.21 \mathrm{a}$ & $70.17 \pm 1.58 \mathrm{a}$ & $78.37 \pm 1.94 \mathrm{a}$ \\
& $\mathrm{NaCl}: \mathrm{CK}$ & 8.34 & 4.08 & 5.24 & 9.46 \\
\hline & $\mathrm{CK}$ & $14.04 \pm 0.52 \mathrm{~b}$ & $9.03 \pm 0.51 \mathrm{~d}$ & $13.68 \pm 0.36 \mathrm{c}$ & $5.40 \pm 0.15 \mathrm{c}$ \\
A. vulgaris "Variegate" & $\mathrm{NaCl}$ & $65.61 \pm 2.75 \mathrm{a}$ & $57.38 \pm 2.04 \mathrm{~b}$ & $28.61 \pm 1.50 \mathrm{~b}$ & $21.04 \pm 0.72 \mathrm{~b}$ \\
& $\mathrm{NaCl}: \mathrm{CK}$ & 4.67 & 6.35 & 2.09 & 3.90 \\
\hline
\end{tabular}

Values (mean \pm standard errors) with the different letters in the same line are significantly different at $P<0.05$ by Duncan's New Multiple Range Test. CK: $0 \mathrm{mmol} \cdot \mathrm{L}^{-1} \mathrm{NaCl}$ treatment; $\mathrm{NaCl}: 200 \mathrm{mmol} \cdot \mathrm{L}^{-1} \mathrm{NaCl}$ treatment.

TABLE 2: Effects of $\mathrm{NaCl}$ stress on $\mathrm{K}^{+}$content in different organs of A. scoparia and A. vulgaris "Variegate."

\begin{tabular}{lccccc}
\hline Cultivars & Treatment & Roots & \multicolumn{2}{c}{$\mathrm{K}^{+}$content $\left(\mathrm{mg}^{-1}\right.$ dry weight $)$} \\
& & Stems & Middle leaves & Upper leaves \\
\hline & $\mathrm{CK}$ & $55.35 \pm 1.92 \mathrm{a}$ & $81.88 \pm 1.03 \mathrm{a}$ & $64.37 \pm 2.51 \mathrm{a}$ & $72.95 \pm 1.91 \mathrm{a}$ \\
A. scoparia & $\mathrm{NaCl}$ & $25.53 \pm 1.32 \mathrm{c}$ & $60.40 \pm 1.54 \mathrm{bc}$ & $60.32 \pm 1.18 \mathrm{a}$ & $70.89 \pm 0.90 \mathrm{a}$ \\
& $\mathrm{NaCl}: \mathrm{CK}$ & 0.46 & 0.74 & 0.94 & 0.97 \\
\hline & $\mathrm{CK}$ & $37.44 \pm 1.16 \mathrm{~b}$ & $63.57 \pm 1.75 \mathrm{~b}$ & $58.80 \pm 2.35 \mathrm{a}$ & $75.06 \pm 1.98 \mathrm{a}$ \\
A. vulgaris "Variegate" & $\mathrm{NaCl}$ & $22.44 \pm 1.10 \mathrm{c}$ & $51.92 \pm 1.58 \mathrm{c}$ & $64.23 \pm 2.58 \mathrm{a}$ & $74.83 \pm 0.56 \mathrm{a}$ \\
& $\mathrm{NaCl}: \mathrm{CK}$ & 0.60 & 0.82 & 1.09 & 1.00 \\
\hline
\end{tabular}

Values (mean \pm standard errors) with the different letters in the same line are significantly different at $P<0.05$ by Duncan's New Multiple Range Test. CK: $0 \mathrm{mmol} \cdot \mathrm{L}^{-1} \mathrm{NaCl}$ treatment; $\mathrm{NaCl}: 200 \mathrm{mmol} \cdot \mathrm{L}^{-1} \mathrm{NaCl}$ treatment.

the two species were exposed to salt treatment, $\mathrm{Ca}^{2+}$ levels decreased in roots and stems of both species but slightly increased in middle leaves and upper leaves (Table 3).

There were significant reductions in $\mathrm{Mg}^{2+}$ content in roots of both A. scoparia and A. vulgaris "Variegate" after salt stress, but $\mathrm{Mg}^{2+}$ content in stems and leaves of both species was not significantly affected by $\mathrm{NaCl}$ stress. In addition, there was a higher reductions in $\mathrm{Mg}^{2+}$ content in roots of A. scoparia ( $\mathrm{NaCl}: \mathrm{CK}$ is 0.28 ) than in those of $A$. vulgaris "Variegate" ( $\mathrm{NaCl}: \mathrm{CK}$ is 0.63 ), indicating that $\mathrm{Mg}^{2+}$ content in roots of $A$. scoparia was more easily affected by $\mathrm{NaCl}$ than that of A. vulgaris "Variegate" (Table 4).

3.7. Ratios of $\mathrm{K}^{+} / \mathrm{Na}^{+}, \mathrm{Ca}^{2+} / \mathrm{Na}^{+}$, and $\mathrm{Mg}^{2+} / \mathrm{Na}^{+}$in Root, Stem, and Leaves. The ratios of $\mathrm{K}^{+} / \mathrm{Na}^{+}$in all organs of the two species decreased dramatically when they were subjected to $\mathrm{NaCl}$ stress. In addition, the ratios of $\mathrm{K}^{+} / \mathrm{Na}^{+}$in leaves of $A$. vulgaris "Variegate" were significantly higher than those in leaves of $A$. scoparia under $\mathrm{NaCl}$ stress, but there was no significant difference in ratios of $\mathrm{K}^{+} / \mathrm{Na}^{+}$for roots or stems between A. scoparia and A. vulgaris "Variegate" (Table 5). Compared with CK, the transport selectivity of $\mathrm{K}^{+} / \mathrm{Na}^{+}$(designed as $S_{\mathrm{K}, \mathrm{Na}}$ ) was remarkably higher in each organ of $A$. vulgaris "Variegate" treated with $\mathrm{NaCl}$, whereas in A. scoparia, only $S_{\mathrm{K}, \mathrm{Na}}$ from root to stem increased after $\mathrm{NaCl}$ treatment. In addition, $S_{\mathrm{K}, \mathrm{Na}}$ in each organ of $A$. vulgaris "Variegate" was higher than that in the corresponding parts of A. scoparia after $\mathrm{NaCl}$ treatment (Table 6).

There was a significant decrease in the ratios of $\mathrm{Ca}^{2+} / \mathrm{Na}^{+}$ in all organs of both species that were exposed to $\mathrm{NaCl}$ stress. In addition, the ratios of $\mathrm{Ca}^{2+} / \mathrm{Na}^{+}$in all organs of A. vulgaris "Variegate" were much higher than those in the corresponding parts of $A$. scoparia under $\mathrm{NaCl}$ stress (Table 7). The transport selectivity of $\mathrm{Ca}^{2+} / \mathrm{Na}^{+}$(designed as $S_{\mathrm{Ca}, \mathrm{Na}}$ ) from roots to stems increased significantly in $A$. scoparia under salt stress but only slightly from stem to middle leaves and actually decreased from stem to upper leaves. The transporting $S_{\mathrm{Ca}, \mathrm{Na}}$ pattern in A. vulgaris "Variegate" was different. There was a 35\% decrease from roots to stems and substantial increase from stems to middle leaves and from stems to upper leaves (Table 8).

The ratios of $\mathrm{Mg}^{2+} / \mathrm{Na}^{+}$in all organs of both species were decreased under $\mathrm{NaCl}$ stress. In addition, the ratios of $\mathrm{Mg}^{2+} / \mathrm{Na}^{+}$in all organs of A. vulgaris "Variegate" were much higher than in those of $A$. scoparia under salt stress, though there was no significant difference except for upper leaves (Table 9). Compared with CK, transporting $S_{\mathrm{Mg}, \mathrm{Na}}$ both from roots to stems and from stems to middle leaves in A. scoparia was remarkably higher, whereas there was a slight decrease from stems to upper leaves. In A. vulgaris "Variegate", transporting $S_{\mathrm{Mg}, \mathrm{Na}}$ of all parts was higher than CK (Table 10).

3.8. Leaf Ultrastructure. Mesophyll cells of A. scoparia were severely damaged under $\mathrm{NaCl}$ stress (Figures 3(a) and 3(b)), whereas no apparent damage was observed in A. vulgaris "Variegate" (Figures 3(c) and 3(d)). However, $\mathrm{NaCl}$ treatment reduced the number of chloroplasts in mesophyll cells of both species. Chloroplast ultrastructure of $A$. scoparia was more severely affected by $\mathrm{NaCl}$ stress relative to A. vulgaris 
TABLE 3: Effects of $\mathrm{NaCl}$ stress on $\mathrm{Ca}^{2+}$ content in different organs of A. scoparia and A. vulgaris "Variegate."

\begin{tabular}{lccccc}
\hline Cultivars & \multirow{2}{*}{ Treatment } & \multicolumn{3}{c}{$\mathrm{Ca}^{2+}$ content $\left(\mathrm{mg}^{-1}\right.$ dry weight) } \\
& & Roots & Stems & Middle leaves & Upper leaves \\
\hline & $\mathrm{CK}$ & $18.51 \pm 0.66 \mathrm{c}$ & $32.67 \pm 1.76 \mathrm{a}$ & $32.54 \pm 1.99 \mathrm{a}$ & $22.56 \pm 1.25 \mathrm{a}$ \\
A. scoparia & $\mathrm{NaCl}$ & $11.73 \pm 0.64 \mathrm{~d}$ & $23.56 \pm 0.88 \mathrm{bc}$ & $36.27 \pm 0.97 \mathrm{a}$ & $29.53 \pm 1.15 \mathrm{a}$ \\
& $\mathrm{NaCl}: \mathrm{CK}$ & 0.63 & 0.72 & 1.11 & 1.31 \\
\hline & $\mathrm{CK}$ & $62.89 \pm 2.01 \mathrm{a}$ & $31.44 \pm 1.96 \mathrm{ab}$ & $31.61 \pm 1.21 \mathrm{a}$ & $22.85 \pm 1.48 \mathrm{a}$ \\
A. vulgaris "Variegate" & $\mathrm{NaCl}$ & $48.03 \pm 1.53 \mathrm{~b}$ & $21.26 \pm 1.44 \mathrm{c}$ & $32.79 \pm 1.85 \mathrm{a}$ & $25.02 \pm 0.92 \mathrm{a}$ \\
& $\mathrm{NaCl}: \mathrm{CK}$ & 0.76 & 0.68 & 1.04 & 1.09 \\
\hline
\end{tabular}

Values (mean \pm standard errors) with the different letters in the same line are significantly different at $P<0.05$ by Duncan's New Multiple Range Test. CK: $0 \mathrm{mmol} \cdot \mathrm{L}^{-1} \mathrm{NaCl}$ treatment; $\mathrm{NaCl}: 200 \mathrm{mmol} \cdot \mathrm{L}^{-1} \mathrm{NaCl}$ treatment.

TABLE 4: Effects of $\mathrm{NaCl}$ stress on $\mathrm{Mg}^{2+}$ content in different organs of A. scoparia and A. vulgaris "Variegate."

\begin{tabular}{lccccc}
\hline Cultivars & \multirow{2}{*}{ Treatment } & \multicolumn{3}{c}{$\mathrm{Mg}^{2+}$ content $\left(\mathrm{mg} \cdot \mathrm{g}^{-1}\right.$ dry weight) } \\
& & Roots & Stems & Middle leaves & Upper leaves \\
\hline & $\mathrm{CK}$ & $2.63 \pm 0.21 \mathrm{c}$ & $2.10 \pm 0.17 \mathrm{~b}$ & $5.63 \pm 0.23 \mathrm{a}$ & $4.77 \pm 0.30 \mathrm{a}$ \\
A. scoparia & $\mathrm{NaCl}$ & $0.74 \pm 0.05 \mathrm{~d}$ & $2.20 \pm 0.07 \mathrm{~b}$ & $6.06 \pm 0.30 \mathrm{a}$ & $5.60 \pm 0.24 \mathrm{a}$ \\
& $\mathrm{NaCl}: \mathrm{CK}$ & 0.28 & 1.05 & 1.08 & 1.17 \\
\hline & $\mathrm{CK}$ & $14.88 \pm 0.56 \mathrm{a}$ & $4.92 \pm 0.35 \mathrm{a}$ & $4.55 \pm 0.28 \mathrm{a}$ & $4.23 \pm 0.25 \mathrm{a}$ \\
A. vulgaris "Variegate" & $\mathrm{NaCl}$ & $9.31 \pm 0.53 \mathrm{~b}$ & $5.31 \pm 0.18 \mathrm{a}$ & $4.93 \pm 0.33 \mathrm{a}$ & $4.98 \pm 0.38 \mathrm{a}$ \\
& $\mathrm{NaCl}: \mathrm{CK}$ & 0.63 & 1.08 & 1.08 & 1.18 \\
\hline
\end{tabular}

Values (mean \pm standard errors) with the different letters in the same line are significantly different at $P<0.05$ by Duncan's New Multiple Range Test. CK: $0 \mathrm{mmol} \cdot \mathrm{L}^{-1} \mathrm{NaCl}$ treatment; $\mathrm{NaCl}: 200 \mathrm{mmol} \cdot \mathrm{L}^{-1} \mathrm{NaCl}$ treatment.

TABLE 5: Effect of $\mathrm{NaCl}$ stress on the ratios of $\mathrm{K}^{+} / \mathrm{Na}^{+}$in different parts of seedlings.

\begin{tabular}{lccccc}
\hline Materials & Treatment & Roots & Stems & Middle leaves & Upper leaves \\
\hline \multirow{2}{*}{ A. scoparia } & $\mathrm{CK}$ & $6.85 \pm 0.28 \mathrm{a}$ & $4.56 \pm 0.08 \mathrm{~b}$ & $4.81 \pm 0.09 \mathrm{a}$ & $8.81 \pm 0.27 \mathrm{~b}$ \\
& $\mathrm{NaCl}$ & $0.38 \pm 0.02 \mathrm{c}$ & $0.82 \pm 0.00 \mathrm{c}$ & $0.86 \pm 0.01 \mathrm{c}$ & $0.90 \pm 0.03 \mathrm{~d}$ \\
A. vulgaris "Variegate" & $\mathrm{CK}$ & $2.68 \pm 0.18 \mathrm{~b}$ & $7.10 \pm 0.54 \mathrm{a}$ & $4.31 \pm 0.23 \mathrm{a}$ & $13.91 \pm 0.24 \mathrm{a}$ \\
& $\mathrm{NaCl}$ & $0.34 \pm 0.03 \mathrm{c}$ & $0.91 \pm 0.03 \mathrm{c}$ & $2.26 \pm 0.17 \mathrm{~b}$ & $3.56 \pm 0.09 \mathrm{c}$ \\
\hline
\end{tabular}

Values (mean \pm standard errors) with the different letters in the same line are significantly different at $P<0.05$ by Duncan's New Multiple Range Test. CK: $0 \mathrm{mmol} \cdot \mathrm{L}^{-1} \mathrm{NaCl}$ treatment; $\mathrm{NaCl}: 200 \mathrm{mmol} \cdot \mathrm{L}^{-1} \mathrm{NaCl}$ treatment.

TABLE 6: Effect of $\mathrm{NaCl}$ stress on absorbing and transporting selectivity ratios of $\mathrm{K}^{+}$to $\mathrm{Na}^{+}$in seedlings.

\begin{tabular}{lccccc}
\hline Materials & Treatment & Root absorption & From roots to stems & From stems to middle leaves & From stems to upper leaves \\
\hline \multirow{2}{*}{ A. scoparia } & $\mathrm{CK}$ & 0.01 & 0.67 & 1.06 & 1.93 \\
& $\mathrm{NaCl}$ & 12.58 & 2.18 & 1.04 & 1.10 \\
A. vulgaris "Variegate" & $\mathrm{CK}$ & 0.00 & 2.64 & 0.61 & 1.98 \\
& $\mathrm{NaCl}$ & 11.38 & 2.65 & 2.48 & 3.93 \\
\hline
\end{tabular}

CK: $0 \mathrm{mmol} \cdot \mathrm{L}^{-1} \mathrm{NaCl}$ treatment; $\mathrm{NaCl}: 200 \mathrm{mmol} \cdot \mathrm{L}^{-1} \mathrm{NaCl}$ treatment.

TABLE 7: Effect of $\mathrm{NaCl}$ stress on the ratios of $\mathrm{Ca}^{2+} / \mathrm{Na}^{+}$in different parts of seedlings.

\begin{tabular}{lccccc}
\hline Materials & Treatment & Roots & Stems & Middle leaves & Upper leaves \\
\hline \multirow{2}{*}{ A. scoparia } & $\mathrm{CK}$ & $2.30 \pm 0.17 \mathrm{~b}$ & $1.82 \pm 0.05 \mathrm{~b}$ & $2.43 \pm 0.05 \mathrm{a}$ & $2.74 \pm 0.05 \mathrm{~b}$ \\
& $\mathrm{NaCl}$ & $0.17 \pm 0.00 \mathrm{~d}$ & $0.32 \pm 0.01 \mathrm{c}$ & $0.52 \pm 0.00 \mathrm{c}$ & $0.38 \pm 0.01 \mathrm{~d}$ \\
A. vulgaris "Variegate" & $\mathrm{CK}$ & $4.50 \pm 0.31 \mathrm{a}$ & $3.53 \pm 0.41 \mathrm{a}$ & $2.32 \pm 0.15 \mathrm{a}$ & $4.25 \pm 0.36 \mathrm{a}$ \\
& $\mathrm{NaCl}$ & $0.74 \pm 0.05 \mathrm{c}$ & $0.37 \pm 0.04 \mathrm{c}$ & $1.15 \pm 0.07 \mathrm{~b}$ & $1.19 \pm 0.05 \mathrm{c}$ \\
\hline
\end{tabular}

Values (mean \pm standard errors) with the different letters in the same line are significantly different at $P<0.05$ by Duncan's New Multiple Range Test. CK: $0 \mathrm{mmol} \cdot \mathrm{L}^{-1} \mathrm{NaCl}$ treatment; $\mathrm{NaCl}: 200 \mathrm{mmol} \cdot \mathrm{L}^{-1} \mathrm{NaCl}$ treatment. 
TABLE 8: Effect of $\mathrm{NaCl}$ stress on absorbing and transporting selectivity ratios of $\mathrm{Ca}^{2+}$ to $\mathrm{Na}^{+}$in seedlings.

\begin{tabular}{|c|c|c|c|c|c|}
\hline Materials & Treatment & Root absorption & From roots to stems & From stems to middle leaves & From stems to upper leaves \\
\hline \multirow{2}{*}{ A. scoparia } & $\mathrm{CK}$ & 0.01 & 0.80 & 1.34 & 1.50 \\
\hline & $\mathrm{NaCl}$ & 8.68 & 1.85 & 1.61 & 1.17 \\
\hline \multirow{2}{*}{ A. vulgaris "Variegate" } & CK & 0.01 & 0.78 & 0.66 & 1.22 \\
\hline & $\mathrm{NaCl}$ & 36.59 & 0.51 & 3.09 & 3.21 \\
\hline
\end{tabular}

CK: $0 \mathrm{mmol} \cdot \mathrm{L}^{-1} \mathrm{NaCl}$ treatment; $\mathrm{NaCl}: 200 \mathrm{mmol} \cdot \mathrm{L}^{-1} \mathrm{NaCl}$ treatment.

TABLE 9: Effect of $\mathrm{NaCl}$ stress on the ratios of $\mathrm{Mg}^{2+} / \mathrm{Na}^{+}$in different parts of seedlings.

\begin{tabular}{lccccc}
\hline Materials & Treatment & Roots & Stems & Middle leaves & Upper leaves \\
\hline A. scoparia & $\mathrm{CK}$ & $0.33 \pm 0.03 \mathrm{~b}$ & $0.12 \pm 0.01 \mathrm{~b}$ & $0.42 \pm 0.00 \mathrm{a}$ & $0.58 \pm 0.03 \mathrm{~b}$ \\
& $\mathrm{NaCl}$ & $0.01 \pm 0.00 \mathrm{c}$ & $0.03 \pm 0.00 \mathrm{~b}$ & $0.09 \pm 0.01 \mathrm{c}$ & $0.07 \pm 0.03 \mathrm{~d}$ \\
A. vulgaris "Variegate" & $\mathrm{CK}$ & $1.07 \pm 0.08 \mathrm{a}$ & $0.55 \pm 0.03 \mathrm{a}$ & $0.33 \pm 0.02 \mathrm{ab}$ & $0.79 \pm 0.06 \mathrm{a}$ \\
& $\mathrm{NaCl}$ & $0.14 \pm 0.00 \mathrm{c}$ & $0.09 \pm 0.00 \mathrm{~b}$ & $0.17 \pm 0.02 \mathrm{bc}$ & $0.24 \pm 0.02 \mathrm{c}$ \\
\hline
\end{tabular}

Values (mean \pm standard errors) with the different letters in the same line are significantly different at $P<0.05$ by Duncan's New Multiple Range Test. CK: $0 \mathrm{mmol} \cdot \mathrm{L}^{-1} \mathrm{NaCl}$ treatment; $\mathrm{NaCl}: 200 \mathrm{mmol} \cdot \mathrm{L}^{-1} \mathrm{NaCl}$ treatment.

TABLE 10: Effect of $\mathrm{NaCl}$ stress on absorbing and transporting selectivity ratios of $\mathrm{Mg}^{2+}$ to $\mathrm{Na}^{+}$in seedlings.

\begin{tabular}{lccccc}
\hline Materials & Treatment & Root absorption & From roots to stems & From stems to middle leaves & From stems to upper leaves \\
\hline \multirow{2}{*}{ A. scoparia } & $\mathrm{CK}$ & 0.00 & 0.36 & 3.60 & 4.93 \\
& $\mathrm{NaCl}$ & 0.54 & 1.48 & 5.28 & 4.37 \\
A. vulgaris "Variegate" & $\mathrm{CK}$ & 0.00 & 0.51 & 0.61 & 1.44 \\
& $\mathrm{NaCl}$ & 6.91 & 0.65 & 1.86 & 2.56 \\
\hline
\end{tabular}

CK: $0 \mathrm{mmol} \cdot \mathrm{L}^{-1} \mathrm{NaCl}$ treatment; $\mathrm{NaCl}: 200 \mathrm{mmol} \cdot \mathrm{L}^{-1} \mathrm{NaCl}$ treatment.

"Variegate". For example, the chloroplasts of A. scoparia mesophyll cells were seriously injured departing from the normal appearance with clear stroma lamellae and large starch grains (Figure 3(e)) to malformed, rounded shape with large interior space and disorganized lamellae (Figure 3(f)). In contrast, chloroplasts of $A$. vulgaris "Variegate" remained relatively normal under the treatment of $\mathrm{NaCl}$, except for smaller starch grains and thinner stacking grana (Figures $3(\mathrm{~g})$ and $3(\mathrm{~h})$ ). In addition, mitochondria of $A$. scoparia were severely affected by $\mathrm{NaCl}$ stress, while those of $A$. vulgaris "Variegate" were seldom influenced. Mitochondria in untreated plants of both species had a normal appearance with intact membranes and cristae (Figures 3(i) and 3(k)). Mitochondria of $A$. scoparia exposed to $\mathrm{NaCl}$ stress became vacuolated and their membranes lost the integrity (Figure 3(j)). However, mitochondria of $A$. vulgaris "Variegate" exposed to $\mathrm{NaCl}$ stress were not seriously affected.

\section{Discussion}

The salt-tolerant ability of plants is controlled by multiple genes that are involved in numerous physiological processes $[1,2,14-16]$. Among them, photoassimilation is inhibited under salt stress and the degree of reduction in photoassimilation is positively proportional to stress strength. The decrease in chlorophyll content under salt stress is due to the increase in activity of chlorophyllase promoting its degradation $[17,18]$. Our results are in accordance with the negative impact of salt stress in chlorophyll content and illustrate well how a species with less sensitivity to salinity is able to maintain its chlorophyll levels when exposed to a high concentration of $\mathrm{NaCl}$.

The dynamic balance between production and removal of reactive oxygen species (ROS) in vivo can be destroyed by salt stress $[19,20]$. Increase in ROS level leads to the accumulation of MDA that can result in peroxidation and delipidation of membrane lipids with a concomitant loss of membrane integrity $[19,21]$. Accumulation of proline under salt stress serves as regulator for cytoplasm osmotic pressure, thus protecting the structures of membranes and enzymes $[21,22]$. In this research, the differential accumulation of proline between $A$. scoparia (susceptible to $\mathrm{NaCl}$ stress) and A. vulgaris "Variegate" (salt tolerant) reflected the adaptive response to salt stress, whereas the increase in content of MDA indicated the degree of cell injury. Organic osmolytes mainly include soluble carbohydrate and organic acids. From the above conclusions, it can be illustrated that both soluble carbohydrate and proline have significant effect on regulating the osmosis.

Plant salt tolerance is determined by the absolute contents of salt ions and priority sequence of ion distribution under organic level $[23,24] . \mathrm{Na}^{+}$contents in all the organs of salttolerant $A$. vulgaris "Variegate" under $\mathrm{NaCl}$ stress were lower than in those salt-sensitive A. scoparia; the stems of $A$. vulgaris "Variegate" also absorbed $\mathrm{Na}^{+}$with a higher degree, 


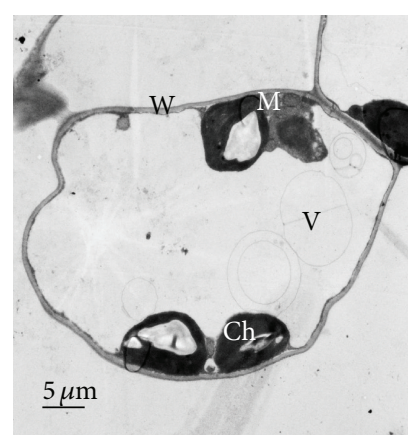

(a)

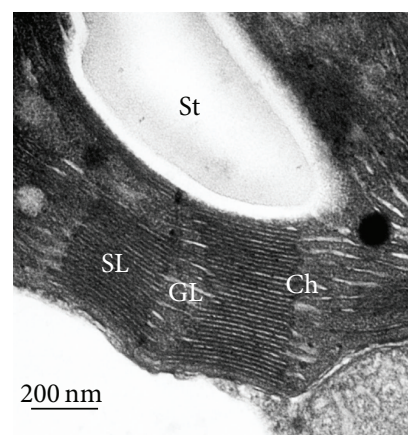

(e)

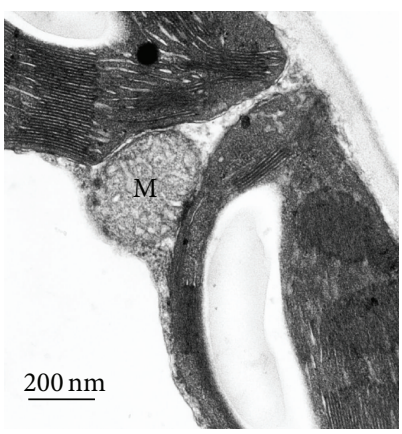

(i)

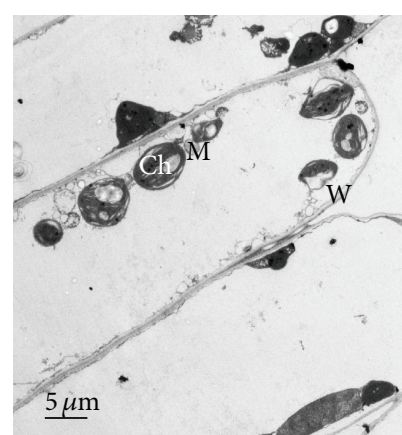

(b)

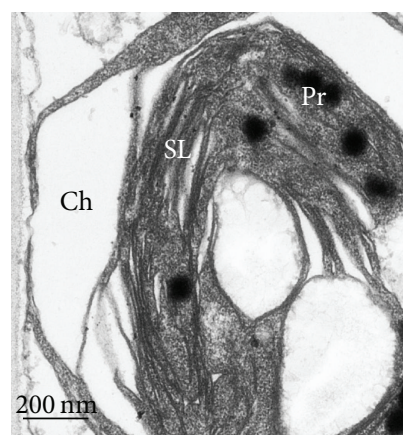

(f)

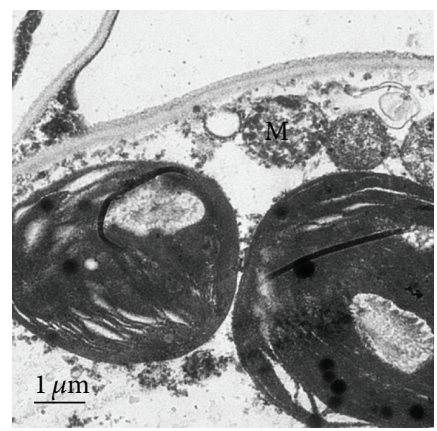

(j)

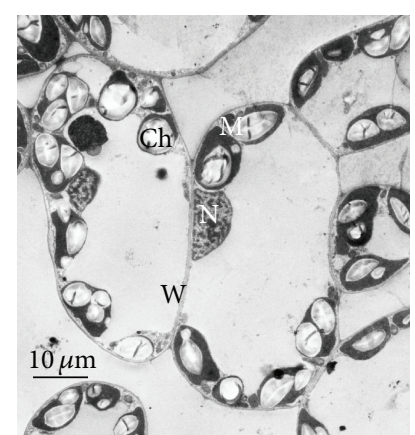

(c)

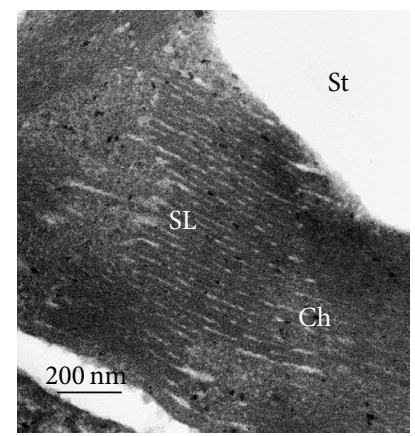

(g)

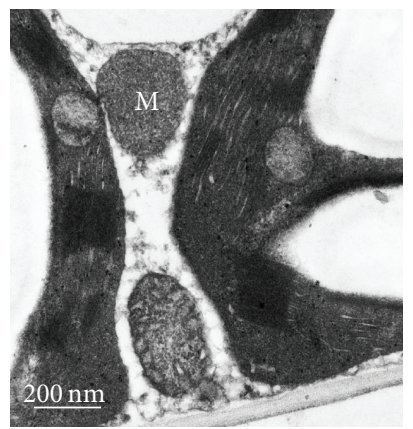

(k)

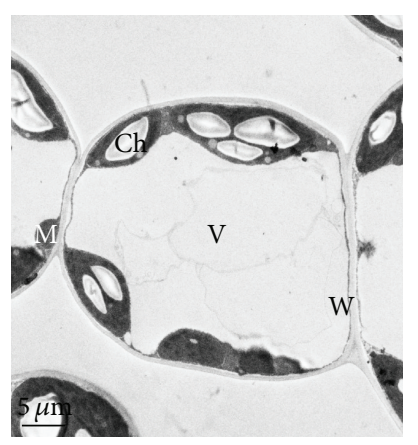

(d)

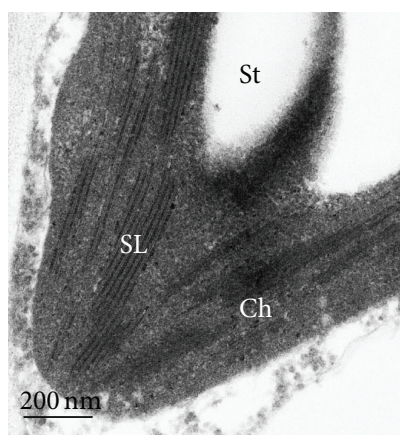

(h)

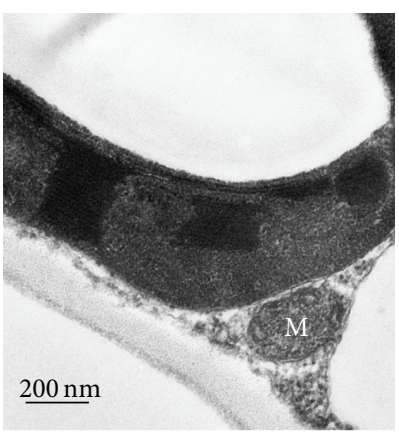

(1)

FIGURE 3: Effect of $\mathrm{NaCl}$ stress on leaf ultrastructure of A. scoparia and A. vulgaris "Variegate". Mesophyll cells of untreated control (a) and NaCl-treated (b) plants of A. scoparia and of A. vulgaris "Variegate" ((c) and (d), resp.). Chloroplasts ((e)-(h)) and mitochondria ((i)-(l)) of the same plants in the same order. Abbreviations: Ch: chloroplast; M: mitochondria; W: cell wall; N: cell nucleus; V: vacuole; St: starch grain; SL: stroma lamelle; GL: grana lamelle; Pr: peroxisome.

which alleviated $\mathrm{Na}^{+}$stress to leaves. The metabolic activity of the stems is relatively lower than that of roots and leaves. Since it mainly serves as transport and support, the ion accumulation in stem can reduce the damage to functional organs [25].

$\mathrm{K}^{+}$is not only a key ion relative to salt tolerance [26], but also the cation in most of higher plants and can regulate physiological functions, such as ion balance, osmosis, protein synthesis, cell turgor, and photosynthesis. Since the ionic radius and hydration energy of $\mathrm{Na}^{+}$and $\mathrm{K}^{+}$are similar, $\mathrm{Na}^{+}$ will compete the absorption and binding sites of $\mathrm{K}^{+}$and lead to the inhibition of enzyme activity and metabolic process which depends on $\mathrm{K}^{+}$. Under salt stress, relatively high $\mathrm{K}^{+}$ content and $\mathrm{K}^{+} / \mathrm{Na}^{+}$ratio can reduce salt damage to plants, which is essential for normal activities of organisms [27, 28]. The ability of A. vulgaris "Variegate" to maintain relatively high $\mathrm{K}^{+} / \mathrm{Na}^{+}$ratio in all the organs under salt stress can partially explain its strong salt tolerance.

The present study illustrated that most $\mathrm{Na}^{+}$was transported into aging organs, while $\mathrm{K}^{+}$was transported into juvenile organs. Meanwhile, relatively high ratios of $\mathrm{K}^{+} / \mathrm{Na}^{+}$, $\mathrm{Ca}^{2+} / \mathrm{Na}^{+}$, and $\mathrm{Mg}^{2+} / \mathrm{Na}^{+}$were effective to enhance salttolerance.

In addition, the relatively low $\mathrm{Ca}^{2+}$ and $\mathrm{Mg}^{2+}$ contents in salt-stressed plants could be attributed to the increase in $\mathrm{Na}^{+}$and $\mathrm{Cl}^{-}$contents [29]. Further, the decrease in $\mathrm{Ca}^{2+}$ and $\mathrm{Mg}^{2+}$ causes unstacking of thylakoid membranes which can be compensated by the supply of higher polyamines, as 
they have strong cationic effects and allow for the stacking of thylakoids [30, 31].

Based on the results for chlorophyll content and damage to the ultrastructure of mesophyll cells, we conclude safely that the high salinity induced stomatal closure leading to reduction in photosynthesis and biomass [32]. Among plant organelles, chloroplast is the most sensitive to salinity injury. For example, salt stress may cause membrane and thylakoid disorganization, which leads to lower photosynthetic efficiency and avoid or alleviate the photo oxidation [33]. Thus it is a mechanism implicated in an adaption to stress. Mitochondria are more stable to stress compared with chloroplast. The close distribution between mitochondria and chloroplasts may be beneficial for the usage of metabolic materials (such as $\mathrm{CO}_{2}, \mathrm{H}_{2} \mathrm{O}$, and $\mathrm{O}_{2}$.), which will compensate for the reduction in cristae and the decrease in metabolic activity [34].

In conclusion, we systematically investigated effects of $\mathrm{NaCl}$ stress on morphological, physiological and structural characteristics of two species in the genus of Artemisia in the current suty. The results indicate that $A$. vulgaris "Variegate" is highly tolerant to salt stress, whereas A. scoparia is very sensitive to salt stress. Therefore, A. vulgaris "Variegate" can be used as the important material in Chrysanthemum hybridization breeding with salt-tolerant improvement in the future. In addition, some physiological and structural parameters can be used for the effective assessment of salt-tolerant ability of many wild species related to Chrysanthemum and even other crops. Finally, the mechanism involved in salttolerant ability will provide valuable information for genetic improvement of salt-tolerant cultivars by plant molecular biotechnology.

\section{Conflict of Interests}

The authors declare that there is no conflict of interests regarding the publication of this paper.

\section{Authors' Contribution}

Zhi-Yong Guan and Yi-Ji Su contributed equally to this work.

\section{Acknowledgments}

This work was supported by 948 Project of Ministry of Agriculture [Grant no. 2013-S13], the National Natural Science Foundation of China (31171983, 31171987), the Program for Science and Technology Support, Jiangsu, China, (BE2012350, BE2011325), Independent Innovation of Agricultural Sciences in Jiangsu Province [CX(12)2020], the Fundamental Research Funds for the Central Universities (KYZ201112, KYZ201147), the Program for New Century Excellent Talents in University of Chinese Ministry of Education (Grant no. NCET-10-0492, NCET-11-0669, NCET12-0890), and a Project Funded by the Priority Academic Program Development of Jiangsu Higher Education Institutions.

\section{References}

[1] R. Munns, "Genes and salt tolerance: bringing them together," New Phytologist, vol. 167, no. 3, pp. 645-663, 2005.

[2] A. Song, J. Lu, J. Jiang et al., "Isolation and characterisation of Chrysanthemum crassum SOS1, encoding a putative plasma membrane $\mathrm{Na}^{+} / \mathrm{H}^{+}$antiporter," Plant Biology, vol. 14, no. 5, p. 706, 2012.

[3] S. W. Yu and Z. C. Tang, Plant Physiology and Molecular Biology, Science Press, Beijing, China, 2nd edition, 1998.

[4] M. Ashraf and P. J. C. Harris, "Potential biochemical indicators of salinity tolerance in plants," Plant Science, vol. 166, no. 1, pp. 3-16, 2004.

[5] V. Chinnusamy, A. Jagendorf, and J.-K. Zhu, "Understanding and improving salt tolerance in plants," Crop Science, vol. 45, no. 2, pp. 437-448, 2005.

[6] M. C. Shannon and C. M. Grieve, "Tolerance of vegetable crops to salinity," Scientia Horticulturae, vol. 78, no. 1-4, pp. 5-38, 1998.

[7] B. J. Yu, Q. Y. Luo, and Y. L. Liu, "Effects of salt stress on growth and ionic distribution of salt-born Glycine soja," Acta Agronomica Sinica, vol. 27, no. 6, pp. 776-780, 2001.

[8] H. B. Yang, M. Chen, and B. S. Wang, " $\mathrm{Na}^{+}$exclusion mechanism of the $\mathrm{Na}^{+}$exclusion sites in wheat seedlings," Journal of Plant Physiology and Molecular Biology, vol. 28, no. 3, pp. 181186, 2002.

[9] S.-P. Wang, S.-R. Guo, X.-H. Hu, Y.-X. Jia, and Y.-S. Jiao, "Effects of $\mathrm{NaCl}$ stress on $\mathrm{K}^{+}, \mathrm{Na}^{+}$and $\mathrm{Cl}^{-}$allocation in different organs of Cucumis sativus L. seedlings," Chinese Journal of Ecology, vol. 26, no. 3, pp. 348-354, 2007.

[10] Y. Deng, S. Chen, A. Lu et al., "Production and characterisation of the intergeneric hybrids between Dendranthema morifolium and Artemisia vulgaris exhibiting enhanced resistance to chrysanthemum aphid (Macrosiphoniella sanbourni)," Planta, vol. 231, no. 3, pp. 693-703, 2010.

[11] Y. Deng, S. Chen, Q. Chang, H. Wang, and F. Chen, "The chrysanthemum $\times$ Artemisia vulgaris intergeneric hybrid has better rooting ability and higher resistance to alternaria leaf spot than its chrysanthemum parent," Scientia Horticulturae, vol. 134, pp. 185-190, 2012.

[12] B. Jin, L. Wang, J. Wang et al., "The effect of experimental warming on leaf functional traits, leaf structure and leaf biochemistry in Arabidopsis thaliana," BMC Plant Biology, vol. 11, article 35, 2011.

[13] F. F. Zhang, Y. L. Wang, Z. Z. Huang et al., "Effects of $\mathrm{CO}_{2}$ enrichment on growth and development of Impatiens hawker," Scientific World Journal, Article ID 601263, 2012.

[14] Y.-J. Xie, S. Xu, B. Han et al., "Evidence of Arabidopsis salt acclimation induced by up-regulation of $H Y 1$ and the regulatory role of RbohD-derived reactive oxygen species synthesis," Plant Journal, vol. 66, no. 2, pp. 280-292, 2011.

[15] H. Shan, S. Chen, J. Jiang et al., "Heterologous expression of the Chrysanthemum R2R3-MYB transcription factor CmMYB2 enhances drought and salinity tolerance, increases hypersensitivity to ABA and delays flowering in Arabidopsis thaliana," Molecular Biotechnology, vol. 51, no. 2, pp. 160-173, 2011.

[16] M. K. Mishra, P. Chaturvedi, R. Singh et al., "Overexpression of WsSGTL1 gene of Withania somnifera enhances salt tolerance, heat tolerance and cold acclimation ability in transgenic Arabidopsis plants," PLOS ONE, vol. 8, no. 4, 2013.

[17] F. Moradi and A. M. Ismail, "Responses of photosynthesis, chlorophyll fluorescence and ROS-scavenging systems to salt 
stress during seedling and reproductive stages in rice," Annals of Botany, vol. 99, no. 6, pp. 1161-1173, 2007.

[18] B. Duarte, D. Santos, J. C. Marques, and I. Cacador, "Ecophysiological adaptations of two halophytes to salt stress: Photosynthesis, PS II photochemistry and anti-oxidant feedbackImplications for resilience in climate change," Plant Physiology and Biochemistry, vol. 67, pp. 178-188, 2013.

[19] A. D. De Azevedo Neto, J. T. Prisco, J. Enéas-Filho, C. E. B. D. Abreu, and E. Gomes-Filho, "Effect of salt stress on antioxidative enzymes and lipid peroxidation in leaves and roots of salttolerant and salt-sensitive maize genotypes," Environmental and Experimental Botany, vol. 56, no. 1, pp. 87-94, 2006.

[20] G. Miller, N. Suzuki, S. Ciftci-Yilmaz, and R. Mittler, "Reactive oxygen species homeostasis and signalling during drought and salinity stresses," Plant, Cell and Environment, vol. 33, no. 4, pp. 453-467, 2010.

[21] H. Koca, M. Bor, F. Özdemir, and I. Türkan, "The effect of salt stress on lipid peroxidation, antioxidative enzymes and proline content of sesame cultivars," Environmental and Experimental Botany, vol. 60, no. 3, pp. 344-351, 2007.

[22] L. Szabados and A. Savouré, "Proline: a multifunctional amino acid," Trends in Plant Science, vol. 15, no. 2, pp. 89-97, 2010.

[23] Y. X. Zhang, F. Liu, E. X. Kang et al., "Study on ion absorption of muskmelon seedlings under $\mathrm{NaCl}$ stress," Plant Nutrition and Fertilizer Science, vol. 4, no. 3, pp. 533-539, 2008.

[24] H. X. Lin, M. Z. Zhu, M. Yano et al., "QTLs for $\mathrm{Na}^{+}$and $\mathrm{K}^{+}$ uptake of the shoots and roots controlling rice salt tolerance," Theoretical and Applied Genetics, vol. 108, no. 2, pp. 253-260, 2004.

[25] H. B. Yang, M. Chen, and B. S. Wang, "Na exclusion mechanism of the Na exclusion sites in wheat seedlings," Journal of Plant Physiology and Molecular Biology, vol. 28, no. 3, pp. 181-186, 2002.

[26] J.-K. Zhu, "Regulation of ion homeostasis under salt stress," Current Opinion in Plant Biology, vol. 6, no. 5, pp. 441-445, 2003.

[27] F. J. M. Maathuis and A. Amtmann, " $\mathrm{K}^{+}$nutrition and $\mathrm{Na}^{+}$ toxicity: the basis of cellular $\mathrm{K}^{+} / \mathrm{Na}^{+}$ratios," Annals of Botany, vol. 84, no. 2, pp. 123-133, 1999.

[28] L. Ding and J.-K. Zhu, "Reduced $\mathrm{Na}^{+}$uptake in the $\mathrm{NaCl}-$ hypersensitive sos1 mutant of Arabidopsis thaliana," Plant Physiology, vol. 113, no. 3, pp. 795-799, 1997.

[29] A. A. Muhammad, "Response of cleopatra mandarin seedlings to a polyamine-biosynthesis inhibitor under salt stress," Acta Physiologiae Plantarum, vol. 32, no. 5, pp. 951-959, 2010.

[30] N. E. Ioannidis and K. Kotzabasis, "Effects of polyamines on the functionality of photosynthetic membrane in vivo and in vitro," Biochimica et Biophysica Acta, vol. 1767, no. 12, pp. 1372-1382, 2007.

[31] N. E. Ioannidis, S. M. Ortigosa, J. Veramendi et al., "Remodeling of tobacco thylakoids by over-expression of maize plastidial transglutaminase," Biochim Biophys Acta, vol. 1787, no. 10, pp. 1215-1222, 2009.

[32] B. Zouhaier, D. Wahbi, C. Wided et al., "Salt impact on photosynthesis and leaf ultrastructure of Aeluropus littoralis," Journal of Plant Research, vol. 120, pp. 529-537, 2007.

[33] H. Fan, K. H. Dong, Y. P. You et al., "Effect of $\mathrm{NaCl}$ stress on ultrastructure of Halophytes Artemisia anethif olia," Acta Agrestia Sinica, vol. 19, no. 3, pp. 582-586, 2011.

[34] J. X. Liu, X. M. Wu, and T. He, "Study of ultrastructure of Phragmites communis mesophyll cell under salt stress," Acta Botanica Boreali-Occidentalia Sinica, vol. 24, pp. 1035-1040, 2004. 


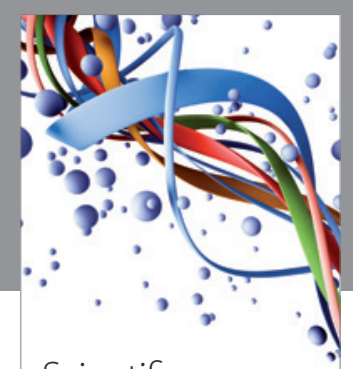

Scientifica
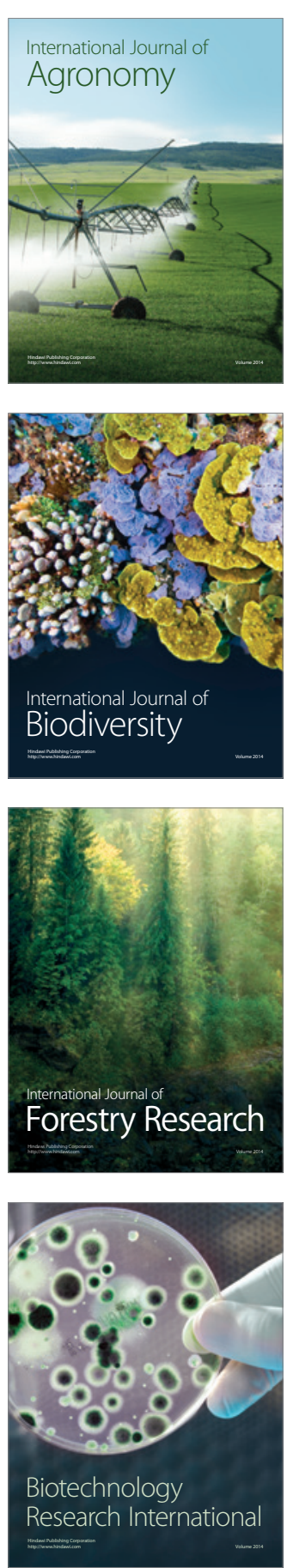
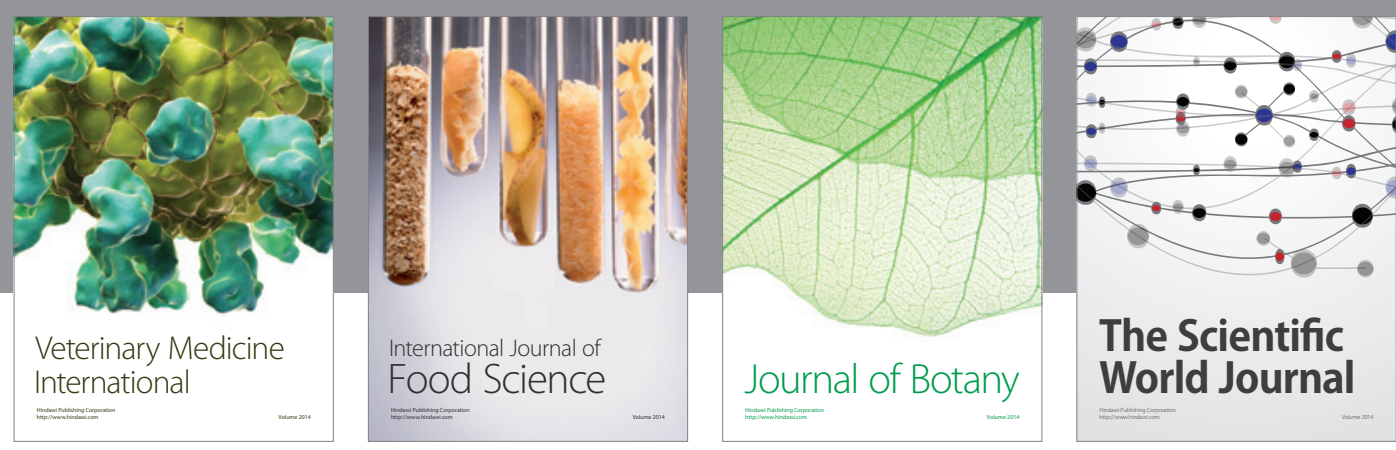

The Scientific World Journal
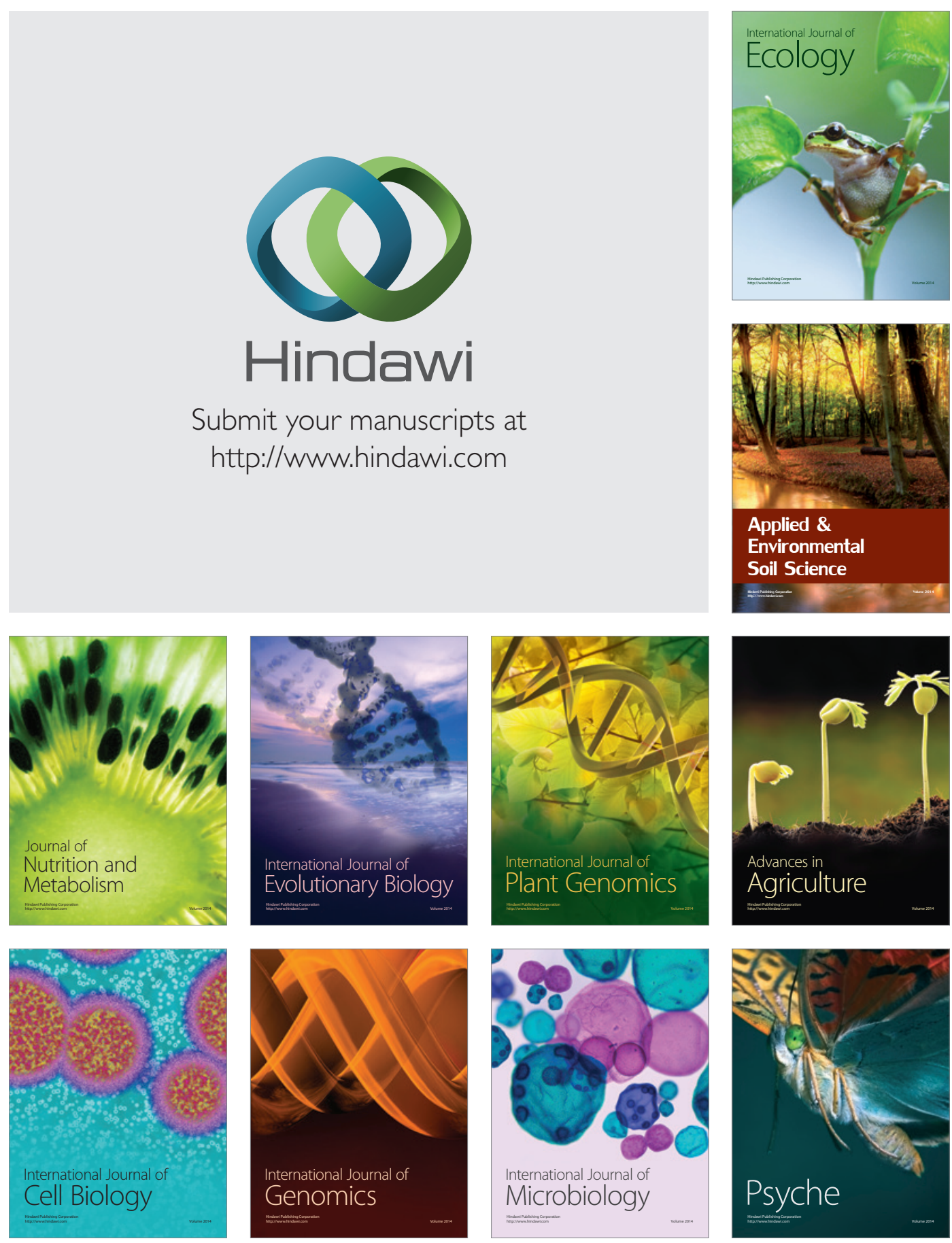